\title{
Evaluation of Rumex hastatus leaves against hepatic fibrosis: a rat model
}

\author{
Sumaira Sahreen ${ }^{1}$, Muhammad Rashid Khan ${ }^{2}$ and Rahmat Ali Khan ${ }^{2,3^{*}}$
}

\begin{abstract}
Background: Rumex hastatus leaves have been widely used as food additive and for the treatment of various liver ailments. According to our previous studies, ethyle acetate (ERL) and methanolic (MRL) fractions of $R$. hastatus leaves are an accessible source of natural antioxidants. In the present research work we arranged to investigate the $R$. hastatus leaves as hepaptoprotective agent verse hepatic damages caused by $\mathrm{CCl}_{4}$.

Methods: During this project we divided 48 rats into eight groups randomly. $\mathrm{CCl}_{4}$-induced damages were assessed through liver function markers viz; alkaline phosphatase (ALP), alanine transaminase (ALT), aspartate transaminase (AST), Y-glutamyltransferase ( $\gamma-G T)$ and lactate dehydrogenase (LDH). Changes in lipid profile were checked by measuring serum total cholesterol (TC), triglycerides (Tg), high density lipoproteins (HDL) and low density lipoproteins $(\mathrm{LDL})$. Antioxidant status was checked by the activities of antioxidant enzymes, DNA damages and cellular abnormalities at histo level.
\end{abstract}

Results: Administration of $\mathrm{CCl}_{4}$ in rats caused significant increase in liver function and lipid profile indicating hepatic damages which were restored by co-administration of $R$. hastatus extracts. Cellular and DNA damages in hepatic tissues were caused by $\mathrm{CCl}_{4}$ which shown clear hepatic fibrosis in addition to disturb antioxidant enzyme level. Co-treatment with various fractions of $R$. hastatus leaves regulated these markers of oxidative dysfunctions.

Conclusion: From the present report it was inferred that $R$. hastatus leaves have the ability to reverse $\mathrm{CCl}_{4}$ - induced hepatic damages.

Keywords: Rumex hastatus, leaves, Carbon tetrachloride, Hepatotoxicity, Oxidative stress, Fibrosis

\section{Background}

Liver fibrosis is an irreversible alteration in the architecture of standard body cells and tissues caused by prolonged hepatic damages, including drug and chemical toxicity. Carbon tetrachloride $\left(\mathrm{CCl}_{4}\right)$ is an effective hepatotoxic agent under laboratory experimentations causes oxidative damages in experimental animal models. $\mathrm{CCl}_{4}$ react with membrane lipids and converting into trichloromethyl radical $\left(. \mathrm{CCl}_{3}\right)$ and finally liver cells fibrosis during chronic cases [1, 2]. Multiple reports revealed that these free radicles also depleted the antioxidant enzymatic and non-enzymatic levels which are linked to hepatic injuries and fibrosis [3]. To control such damages various ways of

\footnotetext{
* Correspondence: rahmatgul_81@yahoo.com

${ }^{2}$ Department of Biochemistry, Faculty of Biological Sciences, Quaid-i-Azam University Islamabad, Islamabad, Pakistan

${ }^{3}$ Department of Biotechnology, Faculty of Biological Sciences, University of Science and Technology, Bannu, KPK 28100, Pakistan

Full list of author information is available at the end of the article
}

treatment are ineffective and few in long-term process have intolerable side effects that is why recently researcher have focused on the use of effective antioxidant for assessment against hepatic fibrosis [4]. Earlier investigations revealed that non enzymatic exogenous antioxidants like sylimarin depleted the oxidation of lipids and partially improved the hepatic damages. Similarly fruits, vegetables and medicinal plants possess active bioactive constituents which showed anti-mutagenic, anti-cancer and hepatoprotective effects [5].

Rumex hastatus D. Don is widely distributed in Pakistan, Afghanistan and China for the treatment of lungs bleeding and skin disorders [6]. Our previous studies verified that the $R$. hastatus leaves are used as a good antioxidant source with sufficient amount of phenolics [7]. Zhang et al. [8] by referring the use in Chinese herbal system reported seven phenolic compounds from $R$. hastatus roots. Sahreen et al. [9] reported that various fractions of Rumex hastatus roots 
showed protective effects against hepato and testicular toxicity caused by $\mathrm{CCl}_{4}$. Singh et al. [10] reported that Rumex hastatus D. Don stem and roots has potent anti-nociceptive, anti-inflammatory and anti-pyretic activities in addition to prevent neurological disorders $[11,12]$. On this bases in the present study we arranged to investigate the hepatoprotective effects of $R$. hastatus against $\mathrm{CCl}_{4}$ induced oxidative damages in rats.

\section{Methods}

\section{Plant collection and extractions}

$R$. hastatus was collected from District Mansehra, Pakistan, recognized and a specimen voucher was submitted in the University Herbarium for further record. Leaves were shed dried, cut into small pieces and ground. Powder sample $(5 \mathrm{~kg})$ was extracted into $70 \%(10 \mathrm{~L})$ methanol and further fractioned through solvent-solvent extraction [7] and kept in refrigerator hepatoprotective investigations.

\section{Ethical committee recommendation for toxicity studies}

Acute toxicity was checked using ARRIVE guidelines, reporting without abnormal observations fulfilling recommendation of ethical committee.

\section{Animals and treatment}

Six-week-old 48 male Sprague-Dawley rats $(180 \pm 10) \mathrm{g}$ were divided randomly into eight groups (6 rats of each group). Group I was control; Group (II) was vehicle control Group (III) rats received $\mathrm{CCl}_{4}(0.5 \mathrm{ml} / \mathrm{kg}$ of b.w.; $20 \% \mathrm{CCl}_{4}$ /olive oil) twice a week for eight weeks; (IV) was administered $50 \mathrm{mg} / \mathrm{kg}$ of b.w., silymarin; (V \& VII) was administered $200 \mathrm{mg} / \mathrm{kg}$ of b.w., fraction of ethyle acetate dose group; (VI \& VIII) the $200 \mathrm{mg} / \mathrm{kg}$ of b.w., methanol extract and groups (IV, V and VI) $0.5 \mathrm{ml} / \mathrm{kg}$ b.w., of $\mathrm{CCl}_{4}$ intragestrictlly twice a week for eight weeks. After the end of experiment all the rats were forfeited; prior to the removal of tissue, blood was obtained via cardiac perforation. The serum was kept at $-80{ }^{\circ} \mathrm{C}$ after parting until it was examined. Half part of the liver was treated for enzyme and genotoxicity assays while the other part was proceed for cellular analysis.

\section{Serum markers assessment}

Serum analysis of various liver marker enzymes such as ALT, AST, ALP, Level of LDH, $\gamma$-GT and lipid profile (Triglycerides, total cholesterol, LDL and LDH) were estimated by using standard AMP diagnostic kits (Stattogger Strasse 31b 8045 Graz, Austria).

\section{Antioxidant enzymes status}

Liver tissue homogenate (10\%) was arranged phosphate buffer. BSA method was used for determination of protein [13]. Activities of enzymes CAT, POD [14] and SOD were determined using standard protocol [15].

\section{Glutathione-S-transferase assay (GST)}

Glutathione-S-transferase activity was assayed by the method of Habig et al. [16]. The reaction mixture was consist of $1.475 \mathrm{ml}$ phosphate buffer $(0.1 \mathrm{~mol}, \mathrm{pH} 6.5)$, $0.2 \mathrm{ml}$ reduced glutathione $(1 \mathrm{mmol}), 0.025 \mathrm{ml}$ (CDNB) ( $1 \mathrm{mmol}$ ) and $0.3 \mathrm{ml}$ of homogenate in a total volume of $2.0 \mathrm{ml}$. The changes in the absorbance were recorded at $340 \mathrm{~nm}$ and enzymes activity was calculated as nmol CDNB conjugate formed $/ \mathrm{min} / \mathrm{mg}$ protein using a molar extinction coefficient of $9.6 \times 10^{3} \mathrm{M}^{-1} \mathrm{~cm}^{-1}$.

\section{Glutathione reductase assay (GR)}

Glutathione reductase activity was determined by method of Carlberg and Mannervik [17]. The reaction mixture consisted of $1.65 \mathrm{ml}$ phosphate buffer: (0.1 mol; pH 7.6), $0.1 \mathrm{ml}$ EDTA $(0.5 \mathrm{mmol}), 0.05 \mathrm{ml}$ oxidized glutathione ( $1 \mathrm{mmol}), 0.1 \mathrm{ml} \mathrm{NADPH}(0.1 \mathrm{mmol})$ and $0.1 \mathrm{ml}$ of homogenate in a total volume of $2 \mathrm{ml}$. Enzyme activity was quantitated at $25{ }^{\circ} \mathrm{C}$ by measuring disappearance of $\mathrm{NADPH}$ at $340 \mathrm{~nm}$ and was calculated as nmol NADPH oxidized $/ \mathrm{min} / \mathrm{mg}$ protein using molar extinction coefficient of $6.22 \times 10^{3} \mathrm{M}^{-1} \mathrm{~cm}^{-1}$.

\section{Glutathione peroxidase assay (GSH-Px)}

Glutathione peroxidase activity was assayed by the method of Mohandas et al. [18]. The reaction mixture was consist of $1.49 \mathrm{ml}$ phosphate buffer $(0.1 \mathrm{~mol}$; pH 7.4), $0.1 \mathrm{ml}$ EDTA (1 mmol), $0.1 \mathrm{ml}$ sodium azide (1 $\mathrm{mmol}), 0.05 \mathrm{ml}$ glutathione reductase $(1 \mathrm{IU} / \mathrm{ml})$, $0.05 \mathrm{ml} \mathrm{GSH}(1 \mathrm{mmol}), 0.1 \mathrm{ml} \mathrm{NADPH}(0.2 \mathrm{mmol})$, $0.01 \mathrm{ml} \mathrm{H}_{2} \mathrm{O}_{2}(0.25 \mathrm{mmol})$ and $0.1 \mathrm{ml}$ of homogenate in a total volume of $2 \mathrm{ml}$. The disappearance of NADPH at $340 \mathrm{~nm}$ was recorded at $25^{\circ} \mathrm{C}$. Enzyme activity was calculated as nmol NADPH oxidized $/ \mathrm{min} / \mathrm{mg}$ protein using molar extinction coefficient of $6.22 \times 10^{3} \mathrm{M}^{-1} \mathrm{~cm}^{-1}$.

\section{Quinone reductase assay (QR)}

The activity of quinone reductase was determined by the method of Benson et al. [19]. The $3.0 \mathrm{ml}$ reaction mixture consisted of $2.13 \mathrm{ml}$ Tris- $\mathrm{HCl}$ buffer $(25 \mathrm{mM}$; $\mathrm{pH} 7.4), 0.7 \mathrm{ml}$ BSA, $0.1 \mathrm{ml}$ FAD, $0.02 \mathrm{ml} \mathrm{NADPH}$ $(0.1 \mathrm{mM})$, and $0.1 \mathrm{ml}$ of homogenate. The reduction of dichloro phenol indophenol (DCPIP) was recorded at $600 \mathrm{~nm}$ and enzyme activity was calculated as nM of DCPIP reduced $/ \mathrm{min} / \mathrm{mg}$ protein using molar extinction coefficient of $2.1 \times 10^{4} \mathrm{M}^{-1} \mathrm{~cm}^{-1}$.

\section{Reduced glutathione assay (GSH)}

Reduced glutathione was estimated by the method of Jollow et al. [20]. $1.0 \mathrm{ml}$ sample of homogenate was precipitated with $1.0 \mathrm{ml}$ of (4\%) sulfosalicylic acid. The samples were kept at $4{ }^{\circ} \mathrm{C}$ for $1 \mathrm{~h}$ and then centrifuged at $1200 \times \mathrm{g}$ for $20 \mathrm{~min}$ at $4{ }^{\circ} \mathrm{C}$. The total volume of $3.0 \mathrm{ml}$ assay mixture contained $0.1 \mathrm{ml}$ filtered aliquot, $2.7 \mathrm{ml}$ 
phosphate buffer (0.1 mol; $\mathrm{pH} 7.4)$ and $0.2 \mathrm{ml} \mathrm{DTNB}$ (100 mmol). The yellow color developed was read immediately at $412 \mathrm{~nm}$ on a SmartSpecTM plus Spectrophotometer. It was expressed as $\mu \mathrm{mol} \mathrm{GSH} / \mathrm{g}$ tissue.

\section{Estimation of lipid peroxidation assay (TBARS)}

The assay for lipid peroxidation was carried out by the modified method of Iqbal et al. [21]. The reaction mixture in a total volume of $1.0 \mathrm{ml}$ contained $0.58 \mathrm{ml}$ phosphate buffer (0.1 mol; pH 7.4), $0.2 \mathrm{ml}$ homogenate sample, $0.2 \mathrm{ml}$ ascorbic acid (100 mmol), and $0.02 \mathrm{ml}$ ferric chloride $(100 \mathrm{mmol})$. The reaction mixture was incubated at $37{ }^{\circ} \mathrm{C}$ in a shaking water bath for $1 \mathrm{~h}$. The reaction was stopped by addition of $1.0 \mathrm{ml} 10 \%$ trichloroacetic acid. Following addition of $1.0 \mathrm{ml} 0.67 \%$ thiobarbituric acid, all the tubes were placed in boiling water bath for $20 \mathrm{~min}$ and then shifted to crushed ice-bath before centrifuging at $2500 \times \mathrm{g}$ for $10 \mathrm{~min}$. The amount of TBARS formed in each of the samples was assessed by measuring optical density of the supernatant at $535 \mathrm{~nm}$ using spectrophotometer against a reagent blank. The results were expressed as $\mathrm{nmol}$ TBARS $/ \mathrm{min} / \mathrm{mg}$ tissue at $37{ }^{\circ} \mathrm{C}$ using molar extinction coefficient of $1.56 \times 10^{5} \mathrm{M}^{-1} \mathrm{~cm}^{-1}$.

\section{DNA fragmentation assay}

DNA fragmentation assay was conducted using the procedure of $\mathrm{Wu}$ et al. [22] with some modifications. The tissue $(50 \mathrm{mg})$ was homogenized in 10 volumes of a TE solution pH 8.0 (5 mmolTris- $\mathrm{HCl}, 20 \mathrm{mmol}$ EDTA) and $0.2 \%$ triton $\mathrm{X}-100.1 .0 \mathrm{ml}$ aliquot of each sample was centrifuged at $27,000 \times \mathrm{g}$ for $20 \mathrm{~min}$ to separate the intact chromatin (pellet, B) from the fragmented DNA (supernatant, $\mathrm{T}$ ). The pellet and supernatant fractions were assayed for DNA content using a freshly prepared DPA (Diphenylamine) solution for reaction. Optical density was read at $620 \mathrm{~nm}$ through spectrophotometer (SmartSpecTMPlus Spectrophotometer catalog \# 170-2525). The results were expressed as amount of fragmented DNA by the following formula;
Fragmented DNA $=\mathrm{Tx} 100 / \mathrm{T}+\mathrm{B}$.

\section{DNA ladder assay}

DNA was isolated by the methods of Wu et al. [22] to estimate DNA damages. $5 \mu \mathrm{g}$ DNA of rats were separately loaded in $1.5 \%$ agarose gel containing $1.0 \mu \mathrm{g} / \mathrm{ml}$ ethidium bromide including DNA standards $(0.5 \mu \mathrm{g}$ per well). Electrophoresis was performed for $45 \mathrm{~min}$ at 100 Volt. After electrophoresis gel was studied under gel doc system and was photographed through digital camera.

\section{Assessment of cellular changes}

Microscopic analysis was conducted to check the cellular abnormalities under light microscope (DIALUX 20 EB) at 10X magnifications.

\section{Statistical analysis}

To determine the treatment effects, one-way analysis of variance was carried by computer software SPSS 13.0. Level of significance among the various treatments was determined by LSD at $0.05 \%$ and $0.01 \%$ level of probability.

\section{Results}

Effects on liver and lipid profile

Administration of $\mathrm{CCl}_{4}$ caused a significant $(p<0.05)$ elevation of liver function profile viz.; $\gamma$-GT, AST, ALT, LDH, ALP and lipid profile as comparatively to nontreated normal rats (Tables 1 and 2). Co-administration significantly $(p<0.05)$ reversed the level of the reported enzymes and lipid profile up to normal level. Silymarin presented same effects on erasing the toxic effects on liver function and lipids parameters viz; total cholesterol, HDL, LDL, and total triglycerides (Tables 1 and 2).

\section{Effects of extract on antioxidant status}

Endogenous antioxidant enzymes play a crucial role in the scavenging of free radicles to improve human health. Effects of various fractions of leaves extract of $R$.

Table 1 Effects of various fractions of $R$. hastatus leaves on liver function tests

\begin{tabular}{llllll}
\hline Group & AST $(\mathrm{U} / \mathrm{l})$ & ALT $(\mathrm{U} / \mathrm{l})$ & ALP $(\mathrm{U} / \mathrm{l})$ & Y-GT $(\mathrm{U} / \mathrm{l})$ & $\mathrm{LDH}(\mathrm{U} / \mathrm{I})$ \\
\hline Control & $98.51 \pm 3.13^{++}$ & $83.93 \pm 2.11^{++}$ & $153.57 \pm 6.18^{++}$ & $2.23 \pm 0.25^{++}$ & $49.72 \pm 3.60^{++}$ \\
Oil + DMSO & $97.86 \pm 3.74^{++}$ & $84.41 \pm 2.78^{++}$ & $151.19 \pm 4.29^{++}$ & $2.20 \pm 0.16^{++}$ & $50.29 \pm 2.31^{++}$ \\
$\mathrm{CCl}_{4}$ & $213.57 \pm 5.70^{* *}$ & $219.32 \pm 3.80^{* *}$ & $450.84 \pm 6.5^{* *}$ & $5.89 \pm 0.36^{* *}$ & $103.62 \pm 3.62^{* *}$ \\
Sily $+\mathrm{CCl}_{4}$ & $134.37 \pm 3.42^{++}$ & $129.28 \pm 2.72^{++}$ & $223.43 \pm 8.83^{++}$ & $3.09 \pm 0.52^{++}$ & $68.72 \pm 2.13^{++}$ \\
ELR $+\mathrm{CCl}_{4}$ & $141.56 \pm 4.86^{++}$ & $131.13 \pm 2.81^{++}$ & $263.72 \pm 12.93^{++}$ & $3.56 \pm 0.27^{++}$ & $71.71 \pm 2.52^{++}$ \\
MLR $+\mathrm{CCl}_{4}$ & $157.82 \pm 3.62^{++}$ & $136.74 \pm 2.89^{++}$ & $276.49 \pm 11.67^{++}$ & $3.24 \pm 0.71^{++}$ & $73.26 \pm 2.48^{++}$ \\
ELR alone & $96.81 \pm 3.21^{++}$ & $85.34 \pm 1.52^{++}$ & $153.26 \pm 8.32^{++}$ & $2.26 \pm 0.16^{++}$ & $48.43 \pm 1.34^{++}$ \\
MLR alone & $95.34 \pm 2.34^{++}$ & $84.34 \pm 2.34^{++}$ & $149.37 \pm 7.25^{++}$ & $2.04 \pm 0.10^{++}$ & $49.36 \pm 2.65^{++}$ \\
\hline
\end{tabular}

Values are Mean \pm SD (06 number), Sily = Silymarin

**indicate significance from the control group at $P<0.05$ and $P<0.01$ probability level

${ }^{++}$indicate significance from the $\mathrm{CCl}_{4}$ group at $P<0.05$ and $P<0.01$ probability level 
Table 2 Effects of various fractions of $R$. hastatus leaves on lipid profile

\begin{tabular}{|c|c|c|c|c|}
\hline Group & $\begin{array}{l}\text { Triglycerides } \\
(\mathrm{mg} / \mathrm{dl})\end{array}$ & $\begin{array}{l}\text { Total cholesterol } \\
(\mathrm{mg} / \mathrm{dl})\end{array}$ & $\mathrm{HDL}(\mathrm{mg} / \mathrm{dl})$ & $\mathrm{LDL}(\mathrm{mg} / \mathrm{dl})$ \\
\hline Control & $125.56 \pm 3.16^{++}$ & $32.43 \pm 1.13^{++}$ & $33.45 \pm 3.78^{++}$ & $30.52 \pm 1.03^{++}$ \\
\hline Oil + DMSO & $124.35 \pm 2.98^{++}$ & $33.00 \pm 2.34^{++}$ & $32.92 \pm 1.43^{++}$ & $30.98 \pm 1.26^{++}$ \\
\hline $\mathrm{CCl}_{4}$ & $239.55 \pm 2.99^{* *}$ & $78.07 \pm 1.12^{* *}$ & $65.64 \pm 2.53^{* *}$ & $42.98 \pm 0.37^{* *}$ \\
\hline Sily $+\mathrm{CCl}_{4}$ & $169.75 \pm 4.67^{++}$ & $46.83 \pm 1.38^{++}$ & $43.98 \pm 2.75^{++}$ & $34.67 \pm 0.15^{++}$ \\
\hline $\mathrm{ELR}+\mathrm{CCl}_{4}$ & $177.42 \pm 4.25^{++}$ & $40.18 \pm 2.28^{++}$ & $40.72 \pm 2.49^{++}$ & $35.14 \pm 0.11^{++}$ \\
\hline $\mathrm{MLR}+\mathrm{CCl}_{4}$ & $187.77 \pm 3.54^{++}$ & $50.34 \pm 3.18^{++}$ & $46.23 \pm 2.98^{++}$ & $33.56 \pm 0.08^{++}$ \\
\hline ELR alone & $121.12 \pm 1.44^{++}$ & $30.41 \pm 1.24^{++}$ & $30.30 \pm 1.01^{++}$ & $29.79 \pm 1.00^{++}$ \\
\hline MLR alone & $122.06 \pm 0.89^{++}$ & $30.86 \pm 1.26^{++}$ & $28.36 \pm 2.90^{++}$ & $30.29 \pm 1.31^{++}$ \\
\hline
\end{tabular}

Values are Mean \pm SD (06 number), Sily = Silymarin

**indicate significance from the control group at $P<0.05$ and $P<0.01$ probability level

${ }^{++}$indicate significance from the $\mathrm{CCl}_{4}$ group at $P<0.05$ and $P<0.01$ probability level

hastatus on antioxidant profile are presented in Table 3. Treatment of $\mathrm{CCl}_{4}$ considerably $(p<0.05)$ reduced the protein contents and antioxidant enzymes activity comparatively to normal non treated rats. Co-administration of fractions revealed significant enhancement the antioxidant enzyme level near to control group versus the $\mathrm{CCl}_{4}$ toxicity.

TBARS play an important role in the assessment of antioxidant activities. Treatment of $\mathrm{CCl}_{4}$ caused marked $(p<0.05)$ increase in the level of TBARS which was reimbursed by administration of ethyl acetate (ELR) and methanol extract (MLR) near to control group. Non significant relationship was found by feeding fractions of $R$. hastatus leaves alone against the control group.

Table 4 revealed the effects of fractions on the activities of GR, GPx, QR, GST, GSH and damages of DNA. $\mathrm{CCl}_{4}$ treatment significantly reduced $(p<0.05)$ the GSH contents and activities of QR, GST GPx, and GR comparatively to non-treated normal rats. Co-administration of plant extracts and silymarin significantly $(p<0.05)$ reversed the oxidative abnormalities to normal level.

\section{Effects on DNA damages}

DNA combine with free radicals produced by $\mathrm{CCl}_{4}$ making adduct and prompts DNA aberrations in rats liver tissues. Various fraction of plant extracts especially MLR and ELR as well as silymarin improved the damages comparatively to control rats as shown in Fig. 1.

\section{Effects of $R$. hastatus leaves on hepatic histology}

Cellular changes provide a strong support for biochemical and molecular reports. H \& E staining were used for determination of the cellular observations as shown in Fig. 2. $\mathrm{CCl}_{4}$ administration produced noticeable amplification in cellular hypertrophy, inflammatory cells infiltrations, fatty changes, ballooning, the formation of septa, and degeneration of the lobular shape, necrotic foci, congestion and dilation of blood central vein. Coadministration especially ELR and MLR lessened the hepatic damages. Comparable comments were noted by the action of silymarin provides a best result for hepatic biochemical changes.

Table 3 Effects of various fractions of $R$. hastatus leaves on tissue proteins and antioxidant enzyme

\begin{tabular}{llllll}
\hline Group & Protein $(\mu \mathrm{g} / \mathrm{mg}$ tissue $)$ & CAT (U/min) & POD $(\mathrm{U} / \mathrm{min})$ & SOD (U/mg protein) & TBARS (nM/min/mg protein) \\
\hline Control & $3.45 \pm 0.027^{++}$ & $6.16 \pm 0.14^{++}$ & $15.48 \pm 0.20^{++}$ & $5.33 \pm 0.08^{++}$ & $2.46 . \pm 0.15^{++}$ \\
Oil + DMSO & $3.53 \pm 0.007^{++}$ & $6.19 \pm 0.30^{++}$ & $15.48 \pm 0.32^{++}$ & $5.21 \pm 0.41^{++}$ & $2.48 \pm 0.20^{++}$ \\
$\mathrm{CCl}_{4}$ & $1.26 \pm 0.013^{* *}$ & $3.02 \pm 0.24^{* *}$ & $7.54 \pm 0.51^{* *}$ & $2.06 \pm 0.16^{* *}$ & $6.83 \pm 0.46^{* *}$ \\
$\mathrm{Sily}+\mathrm{CCl}_{4}$ & $2.79 \pm 0.018^{++}$ & $5.00 \pm 0.46^{++}$ & $12.94 \pm 0.18^{++}$ & $4.10 \pm 0.52^{++}$ & $3.81 \pm 0.42^{++}$ \\
$\mathrm{ELR}+\mathrm{CCl}_{4}$ & $2.53 \pm 0.028^{++}$ & $5.32 \pm 0.34^{++}$ & $12.65 \pm 0.34^{++}$ & $3.98 \pm 0.17^{++}$ & $3.90 \pm 0.37^{++}$ \\
$\mathrm{MLR}+\mathrm{CCl}_{4}$ & $2.48 \pm 0.041^{++}$ & $4.65 \pm 0.39^{++}$ & $12.09 \pm 0.48^{++}$ & $3.85 \pm 0.35^{++}$ & $4.09 \pm 0.42^{++}$ \\
ELR alone & $3.48 \pm 0.008^{++}$ & $6.28 \pm 0.22^{++}$ & $15.42 \pm 0.17^{++}$ & $5.39 \pm 0.18^{++}$ & $2.46 . \pm 0.07^{++}$ \\
MLR alone & $3.47 \pm 0.029^{++}$ & $6.40 \pm 0.10^{++}$ & $15.76 \pm 0.10^{++}$ & $5.52 \pm 0.08^{++}$ & $2.73 . \pm 0.49^{++}$ \\
\hline
\end{tabular}

Values are Mean \pm SD (06 number). Sily = Silymarin

**indicate significance from the control group at $P<0.05$ and $P<0.01$ probability level

${ }^{++}$indicate significance from the $\mathrm{CCl}_{4}$ group at $P<0.05$ and $P<0.01$ probability level 
Table 4 Effects of various fractions of $R$. hastatus leaves on phase II antioxidant enzymes and DNA fragmentation

\begin{tabular}{lllllll}
\hline Group & $\begin{array}{l}\text { GST }(\mathrm{nM} / \mathrm{min} / \mathrm{mg} \\
\text { protein) }\end{array}$ & $\begin{array}{l}\text { GPx }(\mathrm{nM} / \mathrm{min} / \mathrm{mg} \\
\text { protein) }\end{array}$ & $\begin{array}{l}\mathrm{GR}(\mathrm{nM} / \mathrm{min} / \mathrm{mg} \\
\text { protein) }\end{array}$ & GSH $(\mu M / g$ tissue) & QR (nM/min/mg protein) & DNA damages \% \\
\hline Control & $240.51 \pm 6.19^{++}$ & $180.42 \pm 3.25^{++}$ & $200.29 \pm 3.13^{++}$ & $32.86 \pm 3.22^{++}$ & $148.55 \pm 2.22^{++}$ & $8.13 \pm 1.03^{++}$ \\
Oil + DMSO & $248.35 \pm 3.75^{++}$ & $179.31 \pm 3.56^{++}$ & $202.42 \pm 3.16^{++}$ & $33.41 \pm 4.05^{++}$ & $149.63 \pm 1.79^{++}$ & $8.28 \pm 2.08^{++}$ \\
$\mathrm{CCl}_{4}$ & $125.85 \pm 5.79^{* *}$ & $83.48 \pm 2.39^{* *}$ & $103.38 \pm 2.87^{* *}$ & $12.36 \pm 2.68^{* *}$ & $78.65 \pm 1.37^{* *}$ & $43.68 \pm 1.37^{* *}$ \\
Sily $+\mathrm{CCl}_{4}$ & $196.00 \pm 5.38^{++}$ & $148.84 \pm 2.77^{++}$ & $176.32 \pm 2.17^{++}$ & $24.75 \pm 3.72^{++}$ & $120.17 \pm 1.57^{++}$ & $14.02 \pm 1.80^{++}$ \\
ELR $+\mathrm{CCl}_{4}$ & $180.58 \pm 5.39^{++}$ & $132.23 \pm 2.38^{++}$ & $170.73 \pm 2.26^{++}$ & $25.27 \pm 2.38^{++}$ & $115.17 \pm 1.21^{++}$ & $16.31 \pm 2.02^{++}$ \\
MLR $+\mathrm{CCl}_{4}$ & $187.48 \pm 4.03^{++}$ & $120.78 \pm 3.02^{++}$ & $154.92 \pm 3.96^{++}$ & $21.58 \pm 1.98^{++}$ & $108.75 \pm 2.08^{++}$ & $14.19 \pm 1.46^{++}$ \\
ELR alone & $249.98 \pm 3.34^{++}$ & $185.23 \pm 2.24^{++}$ & $201.29 \pm 4.74^{++}$ & $35.29 \pm 2.24^{++}$ & $149.12 \pm 1.56^{++}$ & $6.89 \pm 1.31^{++}$ \\
MLR alone & $247.34 \pm 3.27^{++}$ & $184.34 \pm 2.87^{++}$ & $204.38 \pm 3.28^{++}$ & $34.26 \pm 2.75^{++}$ & $150.12 \pm 1.10^{++}$ & $7.00 \pm 1.31^{++}$
\end{tabular}

Values are Mean \pm SD (06 number). Sily = Silymarin

**indicate significance from the control group at $P<0.05$ and $P<0.01$ probability level

${ }^{++}$indicate significance from the $\mathrm{CCl}_{4}$ group at $P<0.05$ and $P<0.01$ probability level

\section{Discussion}

Phenolic and poly phenolic compounds lay a crucial role in detoxification of oxidative stress which was present in sufficient quantity in $R$. hastatus leaves [7]. Results of current in vivo project confirmed the protecting probable of $R$. hastatus leaves by reversing the $\mathrm{CCl}_{4}$ induced hepatic damages. Rats have been used as trial animal models to assess the hepatic degenerations caused by $\mathrm{CCl}_{4}$. The toxic effects observed by this induction are same as that of hepatitis. Induction of $\mathrm{CCl}_{4}$ caused generation of trichloromethyl free radical $\left(\mathrm{CCl}_{3}\right)$ in the presence of $\mathrm{P}_{450}$ which further triages lipid peroxidation and hepatic injuries [23]. Lipid peroxidation causes change in the properties of biological molecules and pathogenesis of various diseases.

It has been reported that lipid peroxidation induced genomic overexpression of fibrogenic cytokines and proliferation of collagen which further activates the hepatic stellate cells [4]. Significant results were reported about plant extract and its fractions in amelioration of the $\mathrm{CCl}_{4}$ induced injuries [24]. Kupffer cells generating free radicals which causes increase in serum marker enzymes and structural changes in hepatic cells [25]. In our current research co-administration of fractions significantly

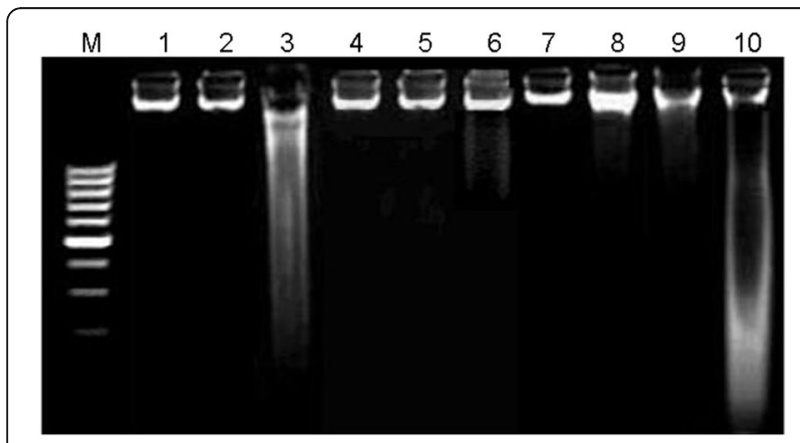

Fig. 1 Agarose gel showing DNA damage by $\mathrm{CCl}_{4}$ and protective effect of $R$. hastatus leaves reduced the serum marker enzymes and proving to improve the damages of structural integrity of the hepatocellular membrane. Similar finding were reported with other study showing anti-fibrotic effects [26].

Fibrosis of liver is a critical community health issue. Liver shows a central role in maintaining cholesterol level. Our results revealed that $\mathrm{CCl}_{4}$-induced hepatic fibrosis and disturbed the total cholesterol (TC) triglycerides, LDL, and HDL levels which are associated with heart disease. Co-administration of $R$. hastatus leaves extracts markedly reverses the toxic effects. Similar reports were obtained while working on Noni fruit juice against $\mathrm{CCl}_{4}$ induced chronic liver damage in female SD rats [5].

Antioxidant enzymes are answerable for catalytic dismutation of highly reactive lethal activists [27]. In our current study various fractions of $R$. hastatus leaves considerably controlled the liver antioxidant enzymes like CAT, POD and SOD representing the failure in oxidative injury produced by $\mathrm{CCl}_{4}$.

Glutathione scheme comprises GSH, GPx, and GST. GSH is a non-enzymatic antioxidant contents taking part in improving and balancing of antioxidant system via detoxification of free radical [28] as well as coordinates other phase II antioxidant enzymes [29, 30]. Our results show significant reduction in the activity of phase II metabolizing enzymes by the induction of $\mathrm{CCl}_{4}$ in rats which prove the free radical induced hepatic damages. Co-administration of $R$. hastatus leaves extracts reduced the $\mathrm{CCl}_{4}$ toxicity, by elevation of GR, GST, quinone reductase and GPx activities comparatively. Other study of co-administration of Coriandrum sativum in rats against $\mathrm{CCl}_{4}$ induced hepatotoxicity [30]. The lipid peroxidation (LPO) is an autocatalytic progression combine with hepatic membrane causes hepatotoxicity which finally induces cell death, aging and cancer [31, 32]. In our current research $\mathrm{CCl}_{4}$ administration caused marked increase in hepatic MDA level representing amplified oxidation of lipid which was restored by co-administration 

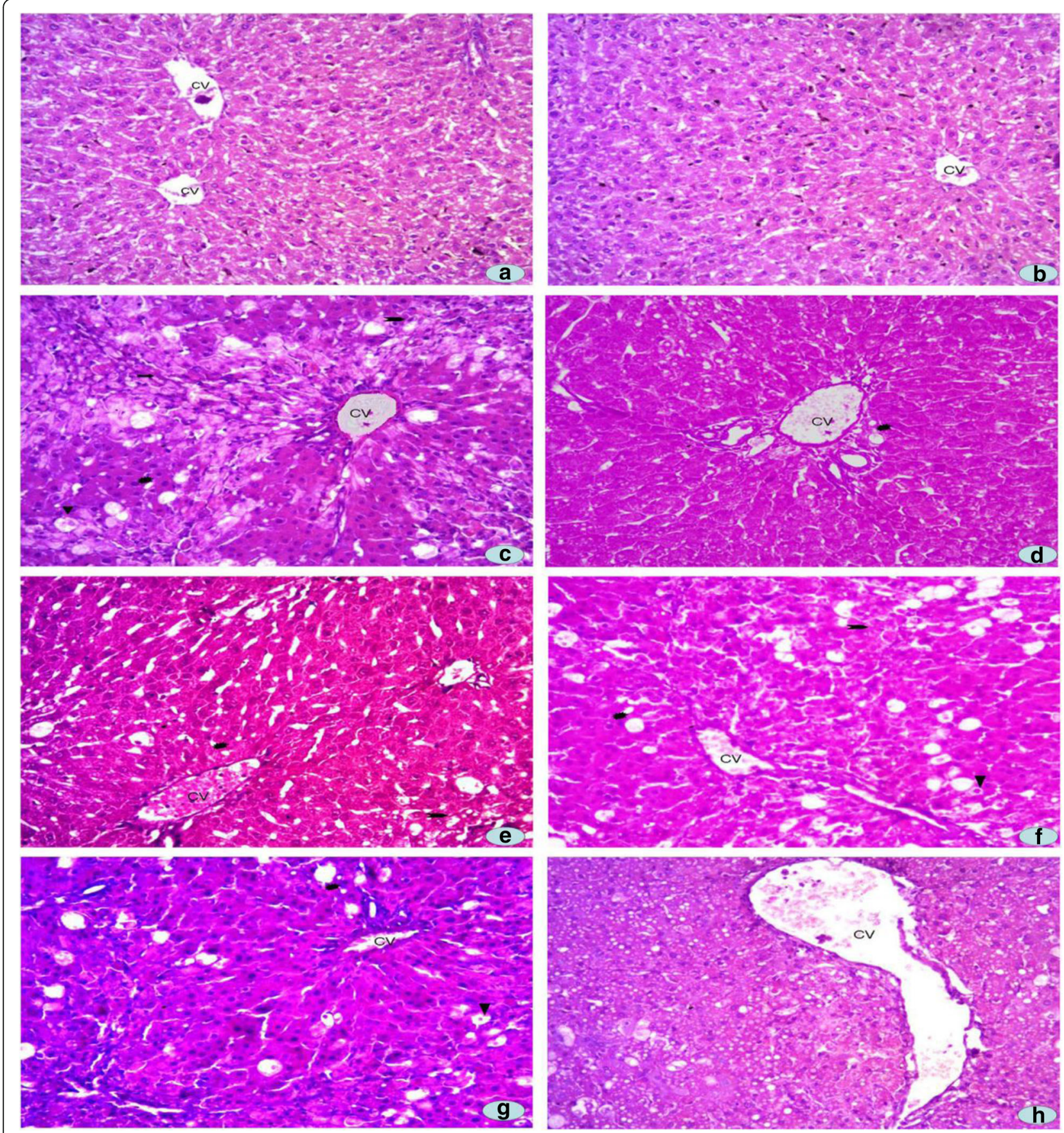

Fig. 2 Microphotograph of rat liver (H \& E stain) $(\rightarrow$ ) fibrosis, $(\bullet)$ cellular hypertrophy, $(\mathbf{\Lambda})$ fatty changes and ballooning: (a) Representative section of liver from the control group showing normal histology, (b) DMSO + Olive oil group, (c) CCl4 group, (d) Silymarin + CCl4 group, (e) ELR + CCl4 group, (f) MLR + CCl4 group, (g) ELR group, (h) MLR group

various fractions of $R$. hastatus leaves and confirmed to be a potent hepatprotective agent.

It has been examined that peroxidation of lipid contents by induction of $\mathrm{CCl}_{4}$ effect DNA structure integrity. MDA associated with DNA forming an adduct MIG (The mutagenic pirimedo-purinone adduct of deoxy-guanosine) by producing reactive species $[19,33]$. Our current reports shows that $\mathrm{CCl}_{4}$ induction caused significant DNA damages quantitatively as well as quantitatively comparatively to non-treated rats. Various fractions considerably condensed the \% DNA damages which were also shown by banding pattern. Same reports are obtained by other studies [21]. 
Cellular architecture provides a direct indication for assessment the protective effect of various fractions of leaves extract ( $R$. hastatus) which provides a clear indication with support of biochemical markers. Intense changes in the LFTs intensely represent the histological indication of cellular degenerations [33, 34]. $\mathrm{CCl}_{4}$ administration caused broad infiltration of lymphocyte, massive fatty changes, cellular hypertrophy, gross necrosis, and collagen deposition which was distinctly reduced by co-treatment of various fractions as well as silymarin. Our results revealed similar exploration which is covenant with previous report [35] during evaluation of extracts against hepatic injuries caused in rats.

\section{Conclusion}

Results of the current study revealed that $R$. hastatus leaves are strong antioxidant and capable to keep the liver from $\mathrm{CCl}_{4}$-induced liver fibrosis and provide some automatous indication for why indigenous people of Southeast Asia found it useful for treating liver ailments as well as food additive.

\section{Acknowledgements}

We thankful to all my friends and college who guided me.

\section{Funding}

No funding is received for conduction of the study.

\section{Availability of data and materials}

Data and material will be available as per Journal rule.

\section{Authors' contributions}

SS completed experimentations and analysis of data, MRK and RAK (ORCID ID: 0000-0003-0453-2090) has made considerable influence to outset and design, analysis of data and drafting of manuscript. All authors read and approved the final manuscript.

\section{Ethics approval and consent to participate}

The study was conducted according to the protocol approved by ethical committee of the University.

\section{Consent for publication}

All the authors are agreeing to submit the paper in your esteemed Journal.

\section{Competing interests}

The authors declare that they have no competing interest.

\section{Publisher's Note}

Springer Nature remains neutral with regard to jurisdictional claims in published maps and institutional affiliations.

\section{Author details}

'Botanical Sciences Division, Pakistan Museum of Natural History, Garden Avenue, Shakarparian, Islamabad, Pakistan. ${ }^{2}$ Department of Biochemistry, Faculty of Biological Sciences, Quaid-i-Azam University Islamabad, Islamabad, Pakistan. ${ }^{3}$ Department of Biotechnology, Faculty of Biological Sciences, University of Science and Technology, Bannu, KPK 28100, Pakistan.
Received: 29 March 2017 Accepted: 21 August 2017

Published online: 30 August 2017

\section{References}

1. He SX, Luo JY, Wang YP, Wang YL, Fu H, Xu JL, et al. Effects of extract from ginkgo biloba on carbon tetrachloride-induced liver injury in rats. World J Gastroenterol. 2006;12(24):3924-8.

2. Shyu MH, Kao TC, Yen GC. Hsian-tsao (Mesona procumbens Heml.) prevents rat liver fibrosis induced by $\mathrm{CCl} 4$ via inhibition of hepatic stellate cells activation. Food Chem Toxicol. 2008;46:3707-13.

3. Liu JY, Chen CC, Wang WH, Hsu JD, Yang MY, Wang CJ. The protective effects of Hibiscus sabdariffa extract on CCl4- induced liver fibrosis in rats. Food Chem Toxicol. 2006:44:336-43.

4. Parola M, Robino G. Oxidative stress-related molecules and liver fibrosis. J Hepatol. 2001;35:297-306.

5. Wang MY, Anderson G, Nowicki D, Jensen J. Hepatic Protection by Noni Fruit Juice Against CCl4-Induced Chronic Liver Damage in Female SD Rats. PI Foods Hum Nut. 2008;63:141-5.

6. Gorsi MS, Miraj S. Ethnomedicinal survey of plants of Khanabad village and its allied areas, district Gilgit. Asian J Plant Sci. 2002;1:604-15.

7. Sahreen S, Khan MR, Khan RA. Comprehensive assessment of phenolics and antioxidant potential of Rumex hastatus D. Don. Roots. BMC Compl Alter Med. 2014;14:40. doi: 10.1186/1472-6882-14-40.

8. Zhang LS, Li Z, Mei RQ. Hastatusides A and B: two new phenolic glucosides from Rumex hastatus. Helvetica Chimica Acta. 2009;92(4):774-8.

9. Sahreen S, Khan MR, Khan RA. Ameliorating effect of various fractions of Rumex hastatus Roots against hepato-and testicular toxicity caused by $\mathrm{CCl}_{4}$ Oxidative Med. Cellular Long. https://doi.org/10.1155/2013/325406.

10. Singh S, Kaur R, Sharma S. Antinociceptive, antiinflammatory and antipyretic activities of Rumex hastatus D. don stem and roots. Der Pharmacia Sinica. 2013:4(3):95-102.

11. Ahmad S, Ullah F, Ayaz M, Sadiq A, Imran M. Antioxidant and anticholinesterase investigations of rumexhastatus D. don: Potential effectiveness in oxidative stress and neurological disorders. Biol Res. 2015:48. doi:10.1186/s40659-015-0010-2.

12. Ahmad S, Ullah F, Ayaz M, Sadiq A, Zeb A, Imran M. Pharmacological evaluation of saponins, methanolic extract and subsequent fractions of Rumex hastatus D. don against monomoriumpharaonis and heterotermesindicola. Pharmacologyonline. 2015;1:13-8.

13. Lowry OH, Rosebrough NJ, Farr AL, Randall RJ. Protein measurement with Folin phenol reagent. J Biol Chem. 1951;193:265-75.

14. Chance B, Maehly AC. Assay of catalase and peroxidases. Method Enzymol. 1955;11:764-75.

15. Kakkar P, Das B, Viswanathan PN. A modified spectrophotomateric assay of superoxide dismutase. Ind J Biochem Biophy. 1984;21:130-2.

16. Habig WH, Pabst MJ, Jakoby WB. Glutathione-S-transferases: the first enzymatic step in mercapturic acid formation. J Biol Chem. 1974;249:7130-9.

17. Carlberg I, Mannervik EB. Glutathione level in rat brain. J Biol Chem. 1975;250:4475-80.

18. Mohandas J, Marshal JJ, Duggin GG, Horvath JS, Tiller DJ. Differential distribution of glutathione and glutathione-related enzymes in rabbit kidney. Possible implications in analgesic nephropathy. Biochem Pharmacol. 1984;33:1801-7.

19. Benson AM, Hunkeler MJ, Talalay P. Increase of NADPH, quinone reductase activity by dietary antioxidant: Possible role in protection against carcinogenesis and toxicity. Proc Nat Aca Sci USA. 1980;77:5216-20.

20. Jollow DJ, Mitchell JR, Zampaglione N, Gillete JR. Bromobenzene induced liver necrosis. Protective role of glutathione and evidence for 3, 4-bromobenzene oxide as a hepatotoxic metabolite. Pharmacology. 1974;1:151-69.

21. Iqbal M, Sharma SD, Zadeh HR, Hasan N, Abdulla M, Athar M. Glutathione metabolizing enzymes and oxidative stress in ferric nitrilotriacetate (Fe-NTA) mediated hepatic injury. Redox Rep. 1996;2:385-91.

22. Wu B, Ootani A, Iwakiri R, Sakata Y, Fujise T, Amemori S, Yokoyama F, Tsunada S, Fujimoto K. T cell deficiency leads to liver carcinogenesis in Azoxymethane-treated rats. Exp Bio Medi. 2005;231:91-8.

23. Lee KJ, Jeong HG. Protective effect of Platycodi radix on carbon tetrachloride-induced hepatotoxicity. Food Chem Toxicol. 2002;40:517-25.

24. Khan RA, Khan MR, Sahreen S. Evaluation of Launaea procumbens use in renal disorders: A rat model. J Ethnopharmacol. 2010;128:452-61.

25. Wang LT, Zhang B, Chen JJ. Effect of anti-fibrosis compound on collagen expression of hepatic cells in experimental liver fibrosis of rats. World J Gastroenterol. 2000;6:877-80. 
26. Xu JW, Gong J, Chang XM, Luo JY, Dong L, Hao ZM, Jia A, XU GP. Estrogen reduces CCL4- induced liver fibrosis in rats. World J Gastroent. 2002;8(5): 883-7.

27. Reiter RJ, Tan D, Osuna C, Gitto E. Actions of melatonin in the reduction of oxidative stress. J Biomed Sci. 2000;7:444-58.

28. Kadiska MB, Gladen BC, Baird DD, Dikalov AE, Sohal RS, Hatch GB, Jones DP, Mason RP, Barret JC. Biomarkers of oxidative stress study: are plasma antioxidants markers of CCl4 poisoning? Free Rad Bio Medi. 2000;28:838-45.

29. Srivastava A, Shivanandappa T. Hepatoprotective effect of the root extract of Decalepis hamiltonii against carbon tetrachloride-induced oxidative stress in rats. Food Chem Toxicol. 2010;118:411-7.

30. Yang YS, Ahn TH, Lee JC, Moon CJ, Kim SH, Jun W, Park SC, Kim HC, Kim JC. Protective effects of Pycnogenol on carbon tetrachloride-induced hepatotoxicity in Sprague-Dawley rats. Food Chem Toxicol. 2008;46:380-7.

31. Sreelatha S, Padma PR, Umadevi M. Protective effects of Coriandrum sativum on carbon tetrachloride-induced hepatotoxicity in rats. Food Chem Toxicol. 2009:47:702-8.

32. Bhadauria M, Nirala SK. Reversal of acetaminophen induced subchronic hepatorenal injury by propolis extract in rats. Envi Toxicol Pharmacol. 2009; 27:17-25.

33. Weber LW, Boll M, Stampfl A. Hepatotoxicity and mechanism of action of haloalkanes: carbon tetrachloride as a toxicological model. Crit Rev Toxicol. 2003;33:105-36.

34. Marnett JL. Oxyradicals and DNA damage. Carcinogenesis. 2000;21:361-70.

35. Chavez E, Gordillo KR, Segovia J, Shibayama M, Tsutsumi VP, Moreno MG, Muriel P. Resveratrol prevents fibrosis NF-k B activation and TGF- $\beta$ increase induced by chronic $\mathrm{CCl}_{4}$ treatment in rats. J Appl Toxicol. 2008;28:35-43.

\section{Submit your next manuscript to BioMed Central} and we will help you at every step:

- We accept pre-submission inquiries

- Our selector tool helps you to find the most relevant journal

- We provide round the clock customer support

- Convenient online submission

- Thorough peer review

- Inclusion in PubMed and all major indexing services

- Maximum visibility for your research

Submit your manuscript at www.biomedcentral.com/submit

) Biomed Central 